\title{
PENGARUH KONSERVATISME AKUNTANSI DAN PENGUNGKAPAN CORPORATE SOCIAL RESPONSIBILITY (CSR) TERHADAP MANAJEMEN LABA (Studi Empiris Pada Perusahaan Pertambangan Yang Terdaftar Di Bursa Efek Indonesia Periode 2015-2017)
}

\author{
Putri Warislan \\ Wirmi Eka Putra \\ Wiwik Tiswiyanti
}

Fakultas Ekonomi dan Bisnis Universitas Jambi

\begin{abstract}
This research was aimed to know the influence of conservatism accounting and corporate social responsibility (CSR) disclosure on earnings management. Variable of conservatism accounting was proxied by accrual. Variable of corporate social responsibility (CSR) disclosure was proxied by corporate social responsibility index (CSRI) which refers to guidelines corporate social responsibility index (CSRI) version GRI-G4 and GRI Standard. Sample used in this research was mining companies listed in IDX (Indonesian Stock Exchange) from 2015 - 2017. Sampling technique used in this research was purposive sampling. Samples collected in this research were 31 companies, a total of 93 data. Data analysis used in this research was descriptive statistics and data panel regression analysis. Software used to run data was evies 7. The results of this research showd as follow. Simultaneously, conservatism accounting and coporate social responsibility (CSR) disclosure had influence on earnings management. Partially, conservatism accounting had influence on earnings management, while corporate social responsibility (CSR) disclosure had no influence on earnings management.
\end{abstract}

Keywords: Conservatism Accounting, Corporate Social Responsibility (CSR) Disclosure, Earnings Management, Data Panel Regression Analysis

\section{PENDAHULUAN}

Perusahaan didirikan dengan tujuan untuk memperoleh laba. Keterbatasan pemilik dalam mengelola perusahaan mendorong pemilik untuk menyerahkan wewenang pengelolaan perusahaan kepada manajemen. Manajemen tersebut nantinya bertanggung jawab kepada pemilik untuk melaporkan kegiatan pengelolaan sumberdaya perusahaan melalui sebuah laporan keuangan. Laporan keuangan berfungsi untuk menyediakan informasi yang menyangkut posisi keuangan, kinerja, serta perubahan posisi keuangan (arus kas) suatu entitas yang bermanfaat bagi sejumlah besar pemakai dalam pengambilan keputusan ekonomi (Hans, Sinaga, \& Syamsul, 2012). Salah satu parameter penting dalam laporan keuangan yang digunakan untuk mengukur kinerja manajemen adalah laba, yang disajikan pada laporan laba rugi.

Adanya kecenderungan memperhatikan laba ini disadari oleh manajemen khususnya manajer yang kinerjanya didasari oleh informasi tersebut, 
sehingga mendorong timbulnya perilaku menyimpang yang salah satu bentuknya adalah manajemen laba atau earnings management. Manajemen laba sendiri menjadi permasalahan serius yang dihadapi oleh praktisi dan akademisi. Alasannya, manajemen laba seolah-olah telah menjadi budaya perusahaan (corporate culture) yang dipraktikkan semua perusahaan di dunia (Ferdiansyah, 2014).

$$
\text { Menurut (Sulistyanto, 2014) }
$$
menyatakan bahwa manajemen laba merupakan proses untuk mengambil langkah tertentu yang disengaja dalam batas-batas prinsip akuntansi berterima umum untuk menghasilkan tingkat yang diinginkan dari laba yang dilaporkan. Upaya untuk merekayasa informasi melalui praktik manajemen laba telah menjadi faktor utama yang menyebabkan laporan keuangan tidak lagi mencerminkan nilai fundamental suatu perusahaan.

Manajemen laba yang dilakukan oleh manajemen timbul sebagai akibat dari adanya perbedaaan kepentingan antara pemilik perusahaan (principal) dan manajemen perusahaan (agent). Teori keagenan berasumsi bahwa setiap individu baik principal maupun agent memilki motivasi dan kepentingan yang berbeda sehingga akan mengakibatkan adanya konflik kepentingan diantara mereka. Manajemen laba memberikan fleksibilitas bagi manajer untuk melindungi diri maupun perusahaan dalam mengantisipasi kejadian-kejadian tak terduga untuk keuntungan pihak-pihak yang terlibat dalam kontrak. Oleh karena itu, manajer akan berusaha untuk memberikan informasi yang akan meningkatkan nilai perusahaan dimata investor. Salah satu faktor yang dapat menyebabkan terjadinya manajemen laba adalah tidak diterapkannya prinsip konservatisme pada perusahaan.

Menurut (Soraya \& Harto, 2014) menyatakan bahwa konservatisma adalah prinsip dalam pelaporan keuangan yang dimaksudkan untuk mengakui dan mengukur aset dan laba yang dilakukan dengan penuh kehati-hatian oleh karena ativitas ekonomi dan bisnis yang dilingkupi ketidakpastian. Walaupun secara konseptual terasa bahwa konservatisme menghasilkan masalah karena konservatisme menyebabkan akuntansi tidak melaporkan true value secara tepat, namun pada kenyataannya prinsip ini masih diterapkan oleh para akuntan. Penelitian yang dilakukan oleh (Ruwanti, 2016) dan (Soraya \& Harto, 2014) menunjukkan bahwa konservatisme akuntansi berpengaruh terhadap manajemen laba. Penelitian ini tidak sejalan dengan penelitian (Ongki \& Pangestu, 2017) yang menyatakan bahwa konservatisme 
tidak berpengaruh terhadap manajemen laba. Hasil penelitian ini juga didukung oleh penelitian (Haque, Mughal, \& Zahid, 2016).

Faktor lain yang dapat menyebabkan terjadinya praktik manajemen laba pada perusahaan adalah penyalahgunaan penilaian yang positif dari pengungkapan laporan keberlanjutan perusahaan secara berkala. Pengungkapan corporate social responsibility (CSR) secara berkala merupakan kegiatan yang penting, artinya perusahaan tersebut turut berpartisipasi dalam meningkatkan kesejahteraan masyarakat. Dampak yang ditimbulkan aktivitas perusahaan, akan sangat mempengaruhi masyarakat sekitar, sehingga apa dilakukan perusahaan terkait aktivitas usahanya akan kembali lagi kepada masyarakat tersebut. Hal inilah yang menjadi alasan mengapa manajemen perusahaan membutuhkan dukungan dari masyarakat sekitar dan lingkungan yang kondusif agar perusahaan dapat beroperasi dengan tenang. Penelitian yang dilakukan (Arief \& Ardiyanto, 2014) serta penelitian (Wardani \& Santi, 2018) menyatakan bahwa corporate social responsibility (CSR) berpengaruh terhadap manajemen laba.

Penelitian ini dimaksudkan untuk melakukan penelitian lebih lanjut mengenai pengaruh konservatisme akuntansi dan pengungkapan corporate social responsibility
(CSR) guna memperoleh pemahaman yang lebih komprehensif mengenai pengaruhnya terhadap manajemen laba. Penelitian yang dilakukan ini merupakan replikasi dari penelitian sebelumnya yang dilakukan oleh (Haque et al., 2016)

Alasan memilih melakukan replikasi pada penelitian ini karena adanya fenomena masalah yang terjadi terkait dengan variabel konservatisme akuntansi yang merupakan salah satu variabel independen dalam penelitian ini. Dikutip dari (Tambang.co.id, 2017) dalam kasus ini Ikatan Karyawan Timah (IKT) yang berasal dari Provinsi Bangka Belitung dan Kepulauan Riau menggelar orasi di depan Kementerian BUMN. Dalam orasinya, karyawan yang berjumlah 30 orang ini menyampaikan tuntutan agar jajaran direksi PT Timah (Persero) Tbk segera mengundurkan diri. Tuntutan ini bukannya tanpa alasan. Menurut Ketua Umum IKT Ali Samsuri, direksi PT Timah (Persero) Tbk saat ini telah banyak melakukan kesalahan dan kelalaian semasa menjabat selama tiga tahun sejak 2013 lalu. IKT menilai direksi telah banyak melakukan kebohongan publik melalui media. Contohnya adalah pada press release laporan keuangan semester I-2015 yang mengatakan bahwa efisiensi dan strategi yang telah membuahkan kinerja yang positif. Padahal kenyataannya 
pada semester I-2015 laba operasi rugi sebesar Rp 59 miliar. Selain mengalami penurunan laba, PT Timah juga mencatatkan peningkatan utang hampir 100 persen dibanding 2013. Pada tahun 2013, utang perseroan hanya mencapai Rp 263 miliar. Namun, jumlah utang ini meningkat hingga $\operatorname{Rp} 2,3$ triliun pada tahun 2015.

PT Timah (Persero) Tbk diduga memberikan laporan keuangan fiktif pada semester I 2015 lalu. Kegiatan laporan keuangan fiktif ini dilakukan guna menutupi kinerja keuangan PT Timah yang terus mengkhawatirkan. Ketua Ikatan Karyawan Timah (IKT), Ali Samsuri mengungkapkan, kondisi keuangan PT Timah sejak tiga tahun belakangan kurang sehat. Ketidakmampuan jajaran Direksi PT Timah keluar dari jerat kerugian telah mengakibatkan penyerahan $80 \%$ wilayah tambang milik PT Timah kepapda mitra usaha. Dari kasus tersebut dapat disimpulkan bahwa perusahaan yang tidak menerapkan prinsip konservatisme akuntansi tidak dapat membatas perilaku opportunistic manajer, sehingga laporan keuangan yang dibuat tidak menggambarkan keadaan sesungguhnya.

Terjadinya skandal keuangan ini dikarenakan kegagalan seorang manajer dalam membuat laporan keuangan untuk memenuhi kebutuhan para pengguna laporan keuangan, seperti investor dan pemerintah. Selain itu penyebab terjadinya skandal tersebut karena tidak diterapkannya prinsip konservatisme akuntansi pada prusahaanperusahaan di Indonesia. Oleh karena itu, penerapan prinsip konservatisme akuntansi pada perusahaan diharapkan dapat meminimalisir praktik manajemen laba.

\section{TINJAUAN PUSTAKA DAN PENGEMBANGAN HIPOTESIS \\ Teori Agensi}

Penelitian ini mendasar pada teori agensi, teori legitimasi dan teori stakeholder. Menurut (Salno, H. M., 2000) konsep manajemen laba menggunakan pendekatan teori keagenan (agency theory) yang menyatakan bahwa "praktek earning management dipengaruhi oleh konflik antara kepentingan manajemen (agent) dan pemilik (principal) yang timbul karena setiap pihak berusaha untuk mencapai atau mempertimbangkan tingkat kemakmuran yang dikehendakinya".

\section{Teori Stakeholder}

Kegiatan CSR yang dilakukan
perusahaan berkaitan dengan teori
stakeholder. Sebuah perusahaan harus
bertanggung jawab kepada pihak-pihak yang
memiliki kepentingan terhadap perusahaan
tersebut. Perusahaan harus membina
hubungan baik dengan para pemangku


kepentingan ini. Menurut (Ghozali \& Chairiri, 2007) dalam stakeholder theory, perusahaan bukanlah entitas yang hanya beroperasi untuk kepentingannya sendiri namun harus memberikan manfaat bagi stakeholdersnya (pemegang saham, kreditor, konsumen, supplier, pemerintah, masyarakat, analis dan pihak lain). Dengan demikian keberadaan suatu perusahaan sangat dipengaruhi oleh dukungan uang yang diberikan oleh stakeholder kepada perusahaan tersebut.

\section{Teori Legitimasi}

Teori legitimasi menjelaskan bahwa perusahaan dituntut untuk melakukan upayaupaya untuk memastikan bahwa perusahaan telah melakukan kegiatan operasionalnya berdasarkan norma atau aturan yang terdapat dalam lingkungan masyarakat. Hal ini dilakukan agar status perusahaan, dan semua kegiatan operasional perusahaan dapat dikatakan sah dan diterima oleh pihak di luar perusahaan.

\section{Manajemen Laba}

Menurut (Sulistyanto, 2014) menyatakan bahwa manajemen laba merupakan proses untuk mengambil langkah tertentu yang disengaja dalam batas-batas prinsip akuntansi berterima umum untuk menghasilkan tingkat yang diinginkan dari laba yang dilaporkan. Menurut (Soraya \&
Harto, 2014) manajemen laba dilakukan dengan mempermainkan komponenkomponen akrual dalam laporan keuangan, sebab pada komponen akrual dapat dilakukan permainan angka melalui metode akuntansi yang digunakan sesuai dengan keinginan orang yang melakukan pencatatan dan penyusunan laporan keuangan.

\section{Konservatisme Akuntansi}

Menurut (Susanto \& Tiara, 2016) konservatisme diartikan sebagai reaksi kehatihatian (prudent reaction) dalam menghadapi ketidakpastian yang terjadi dalam aktivitas ekonomi dan bisnis. (Septian \& Anna, 2014) menyatakan bahwa konsep konservatisme ini sering diungkapkan sebagai preferensi terhadap understatement daripada overstatement dari laba bersih dan aktiva bersih ketika berhadapan dengan ketidakpastian pengukuran.

\section{Pengungkapan Corporate Social}

\section{Responsibility (CSR)}

(Mardikanto, 2014) mendefinisikan CSR sebagai kewajiban pengusaha untuk merumuskan kebijakan, membuat keputusan, atau mengikuti garis tindakan yang diinginkan dalam hal tujuan dan nilai-nilai masyarakat. Pengungkapan kegiatan tanggung jawab sosial (CSR disclosure) merupakan salah satu 
pengungkapan informasi yang dilakukan pihak perusahaan kepada pihak ketiga melalui laporan tahunan.

\section{Pengaruh Konservatisme Akuntansi}

\section{Terhadap Manajemen Laba}

Manajemen mencatatat aset lebih rendah untuk meningkatkan laba pada tahun berikutnya. Tujuannya adalah untuk meningkatkan kompensasi dan menyesatkan pasar modal. Akuntansi bersifat fleksibel yang berarti manajemen dapat memilih metode akuntansi yang akan ditetapkan dalam membuat laporan keuangan. Salah satu metode yang dianut dalam proses pembuatan laporan keuangan adalah konservatisme.

Konservatisma akuntansi menghasilkan laba yang lebih berkualitas karena prinsip ini mencegah perusahaan melakukan tindakan membesar-besarkan laba dan membantu pengguna laporan keuangan dengan menyajikan laba dan aktiva yang tidak overstate. Laba dalam laporan keuangan mampu menginterpretasikan kinerja perusahaan, karena kinerja merupakan salah satu faktor penting yang menunjukkan efektifitas dan efisiensi suatu organisasi dalam rangka mencapai tujuannya (Soraya \& Harto, 2014).

Penelitian yang dilakukan oleh (Ruwanti, 2016) menunjukkan bahwa konservatisme akuntansi berpengaruh terhadap manajemen laba. Semakin konservatif pelaporan keuangan maka semakin kecil para manajer untuk menyalahgunakan informasi keuangan sehingga rendah kemungkinan manajer untuk melakukan manipulasi laba.

H1: Konservatisme Akuntansi Berpengaruh Positif Terhadap Manajemen Laba

\section{Pengaruh Pengungkapan Corporate Social Responsibility (CSR) Terhadap Manajemen Laba}

Perusahaan yang melakukan kegiatan CSR dan mengungkapkannya dalam laporan keuangan secara tidak langsung mendapatkan manfaat berupa image positif dimata masyarakat maupun investor. Image positif tersebut secara tidak langsung menguntungkan manajemen atau perusahaan dalam mengelola laba. (Almahrog, Ali Aribi, \& Arun, 2018) menyatakan bahwa perusahaan dapat memperoleh beberapa keuntungan melalui membangun citra positif di antara para pemangku kepentingan, dan membangun ikatan sosial dengan karyawan dan masyarakat setempat, yang menghasilkan keuntungan reputasi.

Manajemen atau perusahaan lebih leluasa melakukan manajemen laba, karena citra positif tersebut disalahgunakan untuk menutupi tindakan manajemen laba yang 
dilakukan. Kondisi tersebut dimanfaatkan oleh manajemen karena publik telah memberikan penilaian yang baik terhadap perusahaan. Publik berpendapat bahwa perusahaan dengan kegiatan CSR yang tinggi tidak mungkin melakukan tindakan kurang etis seperti manajemen laba.

Penelitian (Arief \& Ardiyanto, 2014) menyatakan bahwa tidak menjamin semakin besar pengungkapan informasi CSR yang dilakukan oleh perusahaan maka semakin luas kesempatan pihak manajemen melakukan manajemen laba. Penelitian ini sejalan dengan yang dilakukan oleh (Siregar, 2017) dan (Wardani \& Santi, 2018) yang menyatakan bahwa CSR berpengaruh terhadap manajemen laba. Penelitian ini tidak sejalan dengan hasil penelitian (Prasetya \& Gayatri, 2016) dan (Putriana, Artati, \& Junica, 2018) yang menyatakan bahwa corporate social responsibility tidak berpengaruh terhadap manajemen laba.

H2: Pengungkapan Corporate Social Responsibility (CSR) Berpengaruh Positif Terhadap Manajemen Laba

\section{METODE PENELITIAN}

Pendekatan penelitian yang digunakan dalam penelitian ini adalah kuantitatif. Penelitian ini bertujuan untuk mengetahui seberapa besar pengaruh konservatisme akuntansi dan pengungkapan corporate social responsibility (CSR) terhadap manajemen laba. Berdasarkan permasalahan penelitian, kajian teoritis dan hasil penelitian-penelitian terdahulu, maka model penelitian ini dapat digambarkan sebagai berikut:

\section{Gambar 1}

\section{Model Penelitian}

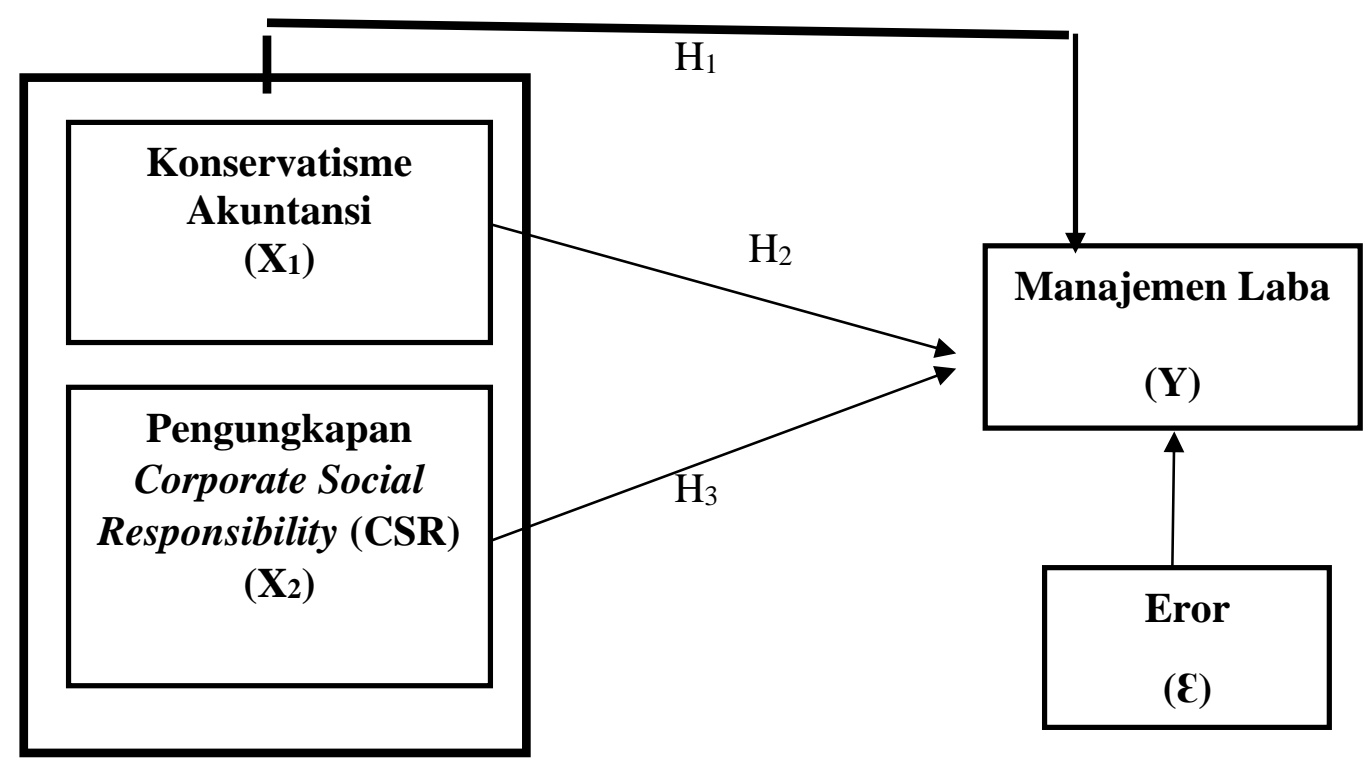


Penelitian ini menggunakan data sekunder. (Indrianto \& Supomo, 2016). Data sekunder dalam penelitian ini berupa laporan tahunan dan laporan keberlanjutan Perusahaan Pertambangan yang terdaftar di BEI selama tahun 2015 - 2017 yang di akses dari www.idx.co.id dan website masing masing perusahaan. Data kuantitatif dalam penelitian ini adalah data keuangan serta angka-angka yang diperlukan untuk menghitung konservatisme akuntansi dan CSR, sedangkan data kualitatif adalah daftar perusahaan Pertambangan yang terdarfar di BEI selama tahun 2015 - 2017.
Populasi penelitian ini adalah Perusahaan Pertambangan yang terdaftar di Bursa Efek indonesia. Perusahaan yang terdaftar sebanyak 45 perusahaan. Periode penelitian menggunakan data laporan keuangan perusahaan Pertambangan tahun 2015-2018. Teknik penarikan sampel penelitian adalah dengan menggunakan metode purposive sampling. Jumlah sampel yang sesuai dengan kriteria penelitian sebanyak 31 perusahaan. Sampel yang dipilih dalam penelitian ini adalah perusahaan Pertambangan yang terdaftar di Bursa Efek Indonesia dengan kriteria sebagai berikut:

\section{Populasi dan Sampel Penelitian}

\section{Tabel 1}

Penentuan Sampel

\begin{tabular}{llc}
\hline No & \multicolumn{1}{c}{ Purposive Sampling } & Jumlah \\
\hline 1. & $\begin{array}{l}\text { Perusahaan Pertambangan yang terdaftar di Bursa Efek } \\
\text { Indonesia. }\end{array}$ & 45 \\
$\begin{array}{l}\text { Dikurangi perusahaan yang tidak menerbitkan laporan tahunan } \\
\text { berturut-turut dan mengaudit laporan keuangan untuk tahun } \\
\text { pelaporan dari 2015 - 2017. }\end{array}$ & (10) \\
3ikurangi perusahaan yang tidak menyajikan data lengkap \\
sesuai dengan variabel dalam penelitian ini.
\end{tabular}

Sumber: Data diolah, 2018

\section{Variabel Penelitian}

Manajemen Laba

Manajemen laba dalam penelitian ini diukur menggunakan discretionary accruals model modifikasi jones. Model ini banyak digunakan dalam penelitian-penelitian akuntansi karena dinilai merupakan model yang paling baik dalam mendeteksi manajemen laba. Ada tiga langkah untuk mengitung nilai discretionary accrual (DAC), yaitu sebagai berikut: 
1. Menghitung total accrual (TAC) yaitu laba bersih tahun $t$ dikurangi arus kas operasi tahun $t$ dengan rumus sebagai berikut:

$$
\mathrm{TAC}=\text { NIit }- \text { CFOit }
$$

Selanjutnya, total accrual (TA) diestimasi dengan Ordinary Least Square sebagai berikut:

$$
\frac{T A i t}{\text { Ait }-1}=\beta 1\left(\frac{1}{\text { Ait-1 }}\right)+\beta 2\left(\frac{\Delta \text { Revit }}{\text { Ait }-1}\right)+\beta 3\left(\frac{P P F i t}{\text { Ait }-1}\right)+\varepsilon
$$

2. Dengan koefisien regresi seperti pada rumus di atas, maka nondiscretionary accruals (NDA) ditentukan dengan formula sebagai berikut:

$$
N D A i t=\beta 1\left(\begin{array}{c}
1 \\
\text { Ait-1 }
\end{array}\right)+\beta 2\left(\begin{array}{l}
\Delta R E V i t \\
\text { Ait }-1
\end{array}-\frac{\Delta R E C i t}{\text { Ait }-1}\right)+\beta 3\left(\begin{array}{c}
\text { PPEit } \\
\text { Ait-1 }
\end{array}\right)
$$

\begin{tabular}{|c|c|c|}
\hline \multirow{2}{*}{\multicolumn{2}{|c|}{ Keterangan : }} & \multirow{3}{*}{ DAit $=\frac{\text { TAit }}{\text { Ait }-1}-N D A i t$} \\
\hline & & \\
\hline DAit & $=$ Discreti & \\
\hline NDAit & \multicolumn{2}{|c|}{$=$ Nondiscretionary Accruals perusahaan i dalam periode tahun $\mathrm{t}$} \\
\hline TAit & \multicolumn{2}{|c|}{$=$ Total akrual perusahaan i dalam periode tahun $\mathrm{t}$} \\
\hline NIit & \multicolumn{2}{|c|}{$=$ Laba bersih perusahaan i dalam periode tahun $\mathrm{t}$} \\
\hline CFOit & \multicolumn{2}{|c|}{$=$ Arus kas dari aktivita, $7 \mathrm{~s}$ operasi perusahaan i dalam periode tahun $\mathrm{t}$} \\
\hline Ait-1 & \multicolumn{2}{|c|}{$=$ Total Assets perusahaan i dalam periode tahun $\mathrm{t}-1$} \\
\hline$\triangle \mathrm{REVit}$ & \multicolumn{2}{|c|}{$\begin{array}{l}\text { = Pendapatan perusahaan i pada tahun } \mathrm{t} \text { dikurangi dengan pendapatan perusahaan i pada } \\
\text { tahun } \mathrm{t}-1\end{array}$} \\
\hline PPEit & \multicolumn{2}{|c|}{$=$ Property, pabrik, dan peralatan perusahaan I dalam periode tahun $\mathrm{t}$} \\
\hline$\triangle \mathrm{RECit}$ & \multicolumn{2}{|c|}{$\begin{array}{l}=\text { Piutang usaha perusahaan i pada tahun } t \text { dikurangi pendapatan perusahaan i pada tahun } \\
\mathrm{t}-1\end{array}$} \\
\hline$\varepsilon$ & \multicolumn{2}{|l|}{$=$ error } \\
\hline
\end{tabular}

3. Terakhir, discretionary accruals (DA) sebagai ukuran manajemen laba ditentukan dengan formula berikut: 


\section{Konservatisme Akuntansi}

Konservatisme diukur dengan menggunakan akrual, yaitu selisih antara net income dan cash flow. Net income yang digunakan adalah net income sebelum depresiasi dan amortisasi, sedangkan cash flow yang digunakan adalah cash flow operasional. Adapun pengukurannya menggunakan rumus sebagai berikut: (Savitri, 2016)

$$
\text { CONAAC }=\frac{(\mathrm{NIO}+\mathrm{DEP}-\mathrm{CFO}) \mathrm{X}-1}{\mathrm{TA}}
$$

Keterangan :

CONAAC = Earnings conservatism based on accrued items

NIO = Operating profit of current year

DEP = Depreciation of fixed assets of current year

$\mathrm{CFO}=$ Net amount of cash flow from operating activities of current year

TA $\quad=$ Book value of closing total assets

Pengunngkapan Corporate Social kategori informasi yang diungkapkan ada Responsibility (CSR) dalam laporan tahunan, dan nilai 0 jika CSR dalam penelitian ini diukur kategori informasi tidak diungkapkan di dengan menggunakan Corporate Social Responsibility Index (CSRI) yang mengacu pada pedoman instrumen Global Instrument Initiative (GRI) versi GRI-G4 dan GRI Standard. Pendekatan ini pada dasarnya menggunakan pendekatan dikotomi, yaitu dalam laporan tahunan. Selanjutnya, skor dari setiap kategori informasi Sustainability Report dijumlahkan untuk memperoleh keseluruhan skor untuk setiap perusahaan. Pengukuran dengan menggunakan rumus sebagai berikut:

setiap kategori informasi pengungkapan CSR

$$
\text { CSRDI }=\frac{\sum X K y}{n y}
$$

Keterangan:

CSRDI = Corporate Sociel Responsibility Index perusahaan $\mathrm{y}$.

$\sum$ Xky $\quad=$ Total dari $1=$ kategori informasi diungkapkan dalam laporan tahunan, $0=$ kategori informasi tidak diungkapkan.

Ny $\quad=$ Jumlah item untuk perusahaan $\mathrm{y}$. 


\section{Metode Analisis Data}

Metode analisis data yang digunakan dalam penelitian ini adalah analisis kuantitatif. Pengolahan data yang digunakan untuk menghasilkan seluruh analisis dalam penelitian ini menggunakan program Eviews 7.0. Metode analisis yang digunakan adalah analisis deskriptif kuantitatif. Analisis

$$
Y_{i t}=\propto+\beta_{1} X_{1 i t}+\beta_{2} X_{2 i t}
$$

Keterangan :

$Y_{i t}$ adalah Manajemen Laba

$\alpha$ adalah konstanta

$\boldsymbol{\beta}_{\mathrm{I}}, \boldsymbol{\beta}_{2}$, adalah koefisien variabel

$X_{1 i t}$ adalah konservatisme akuntansi

$X_{2 i t}$ adalah pengungkapan corporate social responsibility (CSR)

$\varepsilon$ adalah residual of error

\section{HASIL DAN PEMBAHASAN}

\section{Analisis Statistik Deskriptif}

Analisis statistik deskriptif

memberikan gambaran atau deskripsi suatu data yang dilihat dari nilai rata-rata (mean), maksimum, minimum, dan standar deviasi. kuantitatif digunakan untuk menganalisa informasi kuantitatif, yaitu estimasi model regresi dengan pengunaan data panel atau pooled data (pooling cross section-time series regression) dan memilih model mana yang terbaik dari common, fixed, atau random effect. Adapun model regresi data panel sebagai berikut : 


\section{Gambar 1 Statistik Deskriptif}

\section{Manajemen Laba (DA) Perusahaan Pertambangan Tahun 2015-2017}

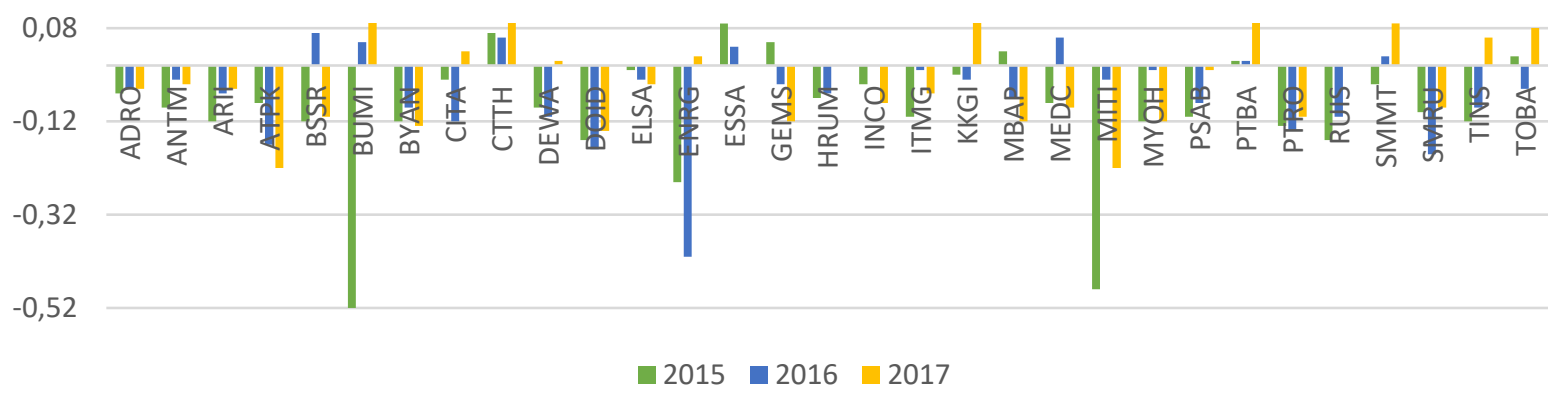

Sumber : Diolah oleh peneliti

Berdasarkan gambar 1 di atas dapat diketahui bahhwa variabel manajemen laba (DA) pada perusahaan pertambangan memilki nilai minimum pada tahun 2015 sebesar -0,52. Pada tahun 2016 memiliki nilai minimum sebesar -0,41. Pada tahun 2017 memiliki nilai minimum sebesar -0,22; Pada tahun 2015 memiliki nilai maksimum sebesar 0,09. Pada tahun 2016 memiliki nilai maksimum sebesar 0,07. Pada tahun 2017 memiliki nilai maksimum sebesar 1,11; Pada tahun 2015 nilai rata - rata yang diperoleh sebesar $-0,10$. Pada tahun 2016 sebesar -0,06 dan pada tahun 2017 sebesar 0,00. Standar deviasi pada tahun 2015 sebesar 0,1311. Pada tahun 2016 sebesar 0,09598 dan tahun 2017 sebesar 0,226.

\section{Gambar 2}

Statistik Deskriptif

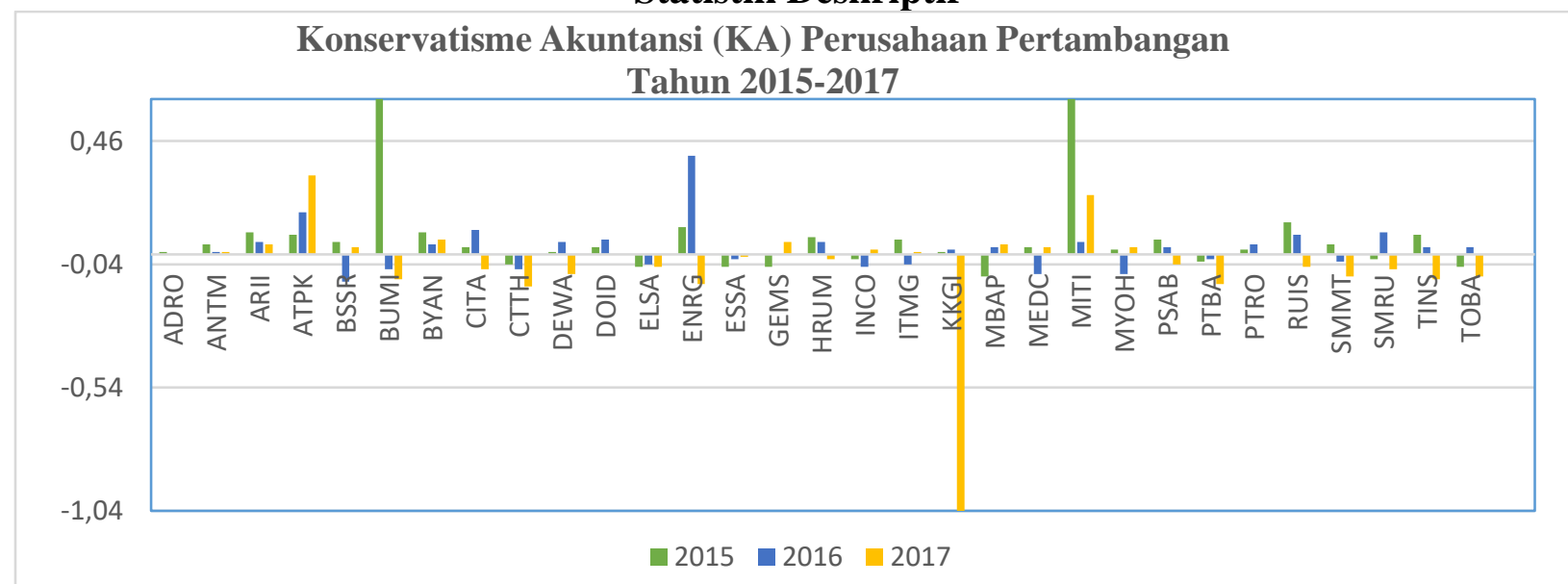

Sumber : Diolah oleh peneliti 
Berdasarkan gambar 2 di atas dapat diketahui bahwa variabel konservatisme akuntansi (KA) pada perusahaan pertambangan memiliki nilai minimum pada tahun 2015 sebesar -0,09. Pada tahun 2016 memiliki nilai minimum sebesar -0,11. Pada tahun 2017 memiliki nilai minimum sebesar 1,04. Pada tahun 2015 memiliki nilai maksimum sebesar 0,63. Pada tahun 2016 memiliki nilai maksimum sebesar 0,40. Pada tahun 2017 memiliki nilai maksimum sebesar 0,32. Pada tahun 2015 nilai rata - rata yang diperoleh sebesar 0,06. Pada tahun 2016 sebesar 0,02 dan pada tahun 2017 sebesar 0,04. Standar deviasi pada tahun 2015 sebesar 0,16136. Pada tahun 2016 sebesar 0.09231 dan tahun 2017 sebesar 0,20876.

Gambar 3 Statistik Deskriptif

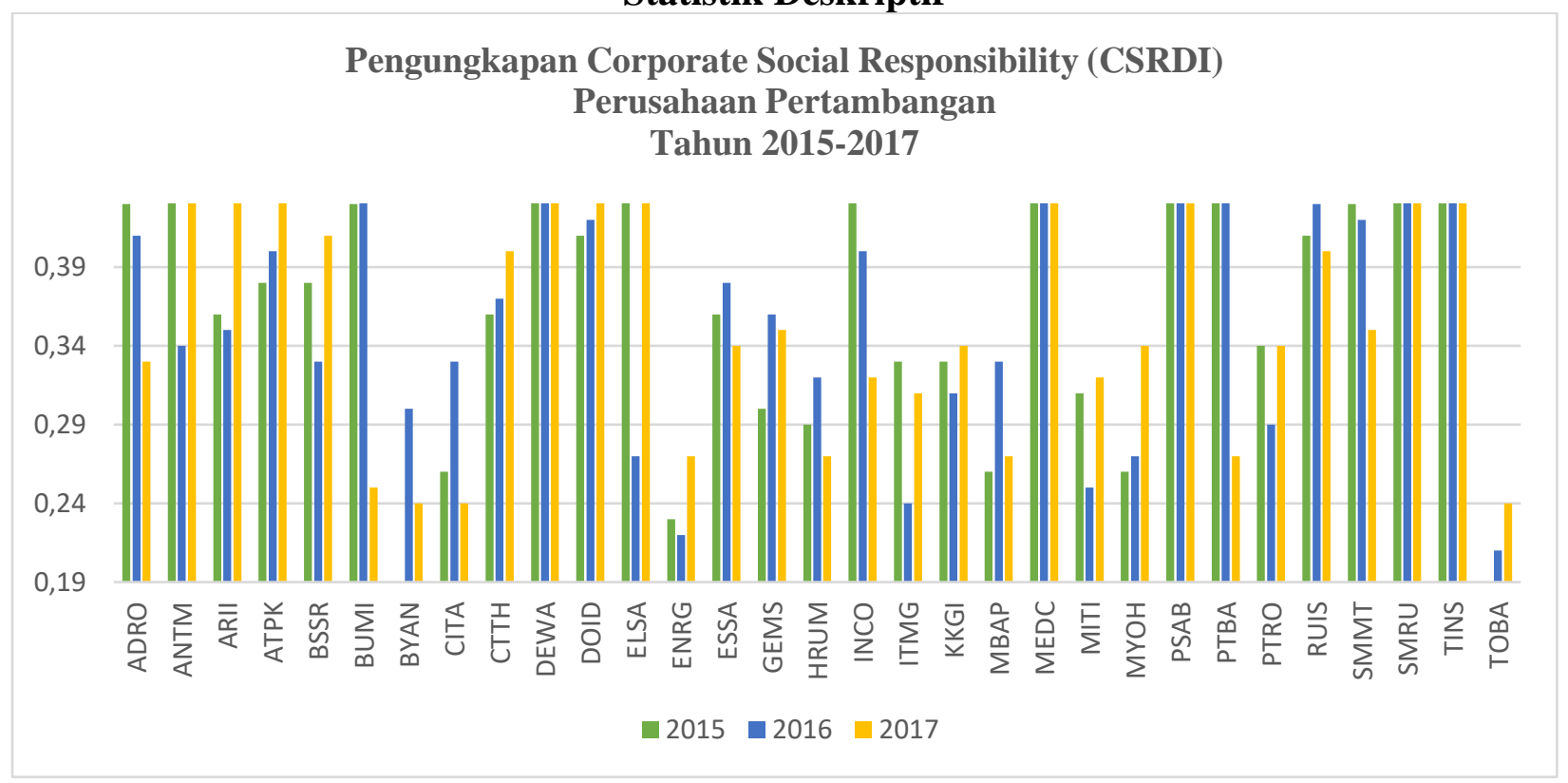

Sumber: Diolah oleh peneliti

Berdasarkan gambar 3 di atas dapat diketahui bahwa variabel pengungkapan corporate social responsibility (CSR) memiliki nilai minimum pada tahun 2015 sebesar 0,19. Pada tahun 2016 memiliki nilai minimum sebesar 0,21. Pada tahun 2017 memiliki nilai minimum sebesar 0,24. Pada tahun 2015 memiliki nilai maksimum sebesar
0,43. Pada tahun 2016 memiliki nilai maksimum sebesar 0,41. Pada tahun 2017 memiliki nilai maksimum sebesar 0,33. Pada tahun 2015 nilai rata - rata yang diperoleh sebesar 0,31. Pada tahun 2016 sebesar 0,31 dan pada tahun 2017 sebesar 0,29. Standar deviasi pada tahun 2015 sebesar 0,17095. 
Pada tahun 2016 sebesar 0,13987 dan tahun 2017 sebesar $0,06216$.
Hasil estimasi dengan menggunakan Common Effect Model (Pooled Least Square) dapat dilihat pada tabel 1 berikut ini:

\section{Tabel 1}

Hasil Estimasi Common Effect (Pooled Least Square)

\begin{tabular}{ccccc}
\hline \hline Variable & Coefficient & Std. Error & t-Statistic & Prob. \\
\hline \hline C & -0.023130 & 0.015921 & -1.452867 & 0.1497 \\
KA? & -0.940836 & 0.032447 & -28.99593 & 0.0000 \\
CSRDI? & -0.038562 & 0.038061 & -1.013168 & 0.3137 \\
\hline \hline
\end{tabular}

\begin{tabular}{lllr}
\hline \hline & Weighted Statistics & \\
\hline \hline R-squared & 0.903379 & Mean dependent var & -0.052241 \\
Adjusted R-squared & 0.901232 & S.D. dependent var & 0.163718 \\
S.E. of regression & 0.051452 & Akaike info criterion & -3.064598 \\
F-statistic & 420.7377 & Durbin-Watson stat & 0.496443 \\
Prob(F-statistic) & 0.000000 & & \\
\hline \hline
\end{tabular}

Sumber: Hasil olah data dengan eviews 7

Berdasarkan $p$-value dari dua variabel independen tersebut ada satu variabel yang memiliki pengaruh signifikan (memiliki $p$ value < 0,05) terhadap variabel dependen yaitu, konservatisme akuntansi (KA) sebesar 0,0000; sedangkan variabel pengungkapan corporate social responsibility (CSR) tidak memiliki pengaruh signifikan (memiliki $p$ value > 0,05) terhadap variabel dependen yaitu sebesar 0.3137. Nilai Adjusted $R$ -
Squared sebesar 0,901232 artinya secara simultan variabel independen terhadap variabel dependen dapat dijelaskan dalam model sebesar 90\% sedangkan 10\% lainnya dapat dijelaskan oleh faktor lain yang tidak termasuk dalam model.

Hasil estimasi dengan menggunakan Fixed Effect Model dapat dilihat pada tabel 2 berikut ini :

Tabel 2

Hasil Estimasi Fixed Effect Model

\begin{tabular}{crrrr} 
Variable & Coefficient & Std. Error & t-Statistic & \multicolumn{1}{c}{ Prob. } \\
\hline \hline C & -0.032081 & 0.016057 & -1.997936 & 0.0503 \\
KA? & -0.954142 & 0.022282 & -42.82085 & 0.0000 \\
CSRDI? & -0.015334 & 0.040168 & -0.381740 & 0.7040
\end{tabular}




\begin{tabular}{lrlr}
\hline \hline \multicolumn{4}{c}{ Effects Specification } \\
\hline \hline Cross-section fixed (dummy variables) & & \\
\hline \hline & Weighted Statistics & -0.052241 \\
\hline \hline R-squared & 0.980951 & Mean dependent var & 0.163718 \\
Adjusted R-squared & 0.970792 & S.D. dependent var & -4.043243 \\
S.E. of regression & 0.027980 & Akaike info criterion & 2.552491 \\
F-statistic & 96.55788 & Durbin-Watson stat & \\
Prob(F-statistic) & 0.000000 & & \\
\hline \hline
\end{tabular}

Sumber : Hasil olah data dengan eviews 7

Berdasarkan $p$-value dari dua variabel yaitu sebesar 0,7040. Nilai Adjusted $R$ independen tersebut ada satu variabel yang Squared yaitu sebesar 0,970792 atau 97\% memiliki pengaruh signifikan (memiliki $p$ - yang dapat dijelaskan dalam model sedangkan value $<0,05)$ terhadap variabel dependen $3 \%$ lainnya dapat dijelaskan oleh faktor lain yaitu, konservatisme akuntansi (KA) sebesar yang tidak termasuk dalam model.

0,0000; sedangkan variabel pengungkapan Hasil estimasi dengan menggunakan corporate social responsibility (CSR) tidak Random Effect Model dapat dilihat pada tabel memiliki pengaruh signifikan (memiliki $p$ - 3 berikut ini:

value > 0,05) terhadap variabel dependen

Tabel 3

Hasil Estimasi Random Effect Model

\begin{tabular}{lllll}
\hline \hline \multicolumn{1}{c}{ Variable } & Coefficient & Std. Error & t-Statistic & Prob. \\
\hline \hline C & -0.029004 & 0.016192 & -1.791276 & 0.0766 \\
KA? & -0.951527 & 0.021530 & -44.19563 & 0.0000 \\
CSRDI? & -0.023245 & 0.034960 & -0.664892 & 0.5078 \\
\hline \hline & & & & \\
\hline \hline & Weighted Statistics & & -0.017729 \\
R-squared & 0.957028 & Mean dependent var & & 0.132225 \\
Adjusted R-squared & 0.956073 & S.D. dependent var & & 0.069119 \\
S.E. of regression & 0.027713 & Sum squared resid & & 1.724804 \\
F-statistic & 1002.198 & Durbin-Watson stat & & \\
Prob(F-statistic) & 0.000000 & & & \\
\hline \hline
\end{tabular}

Unweighted Statistics 


\begin{tabular}{lllr} 
R-squared & 0.903087 & Mean dependent var & -0.052241 \\
Sum squared resid & 0.238981 & Durbin-Watson stat & 0.498855 \\
\hline \hline
\end{tabular}

Sumber : Hasil olah data dengan eviews 7

Berdasarkan $p$-value dari dua variabel simultan variabel independen terhadap independen tersebut ada satu variabel yang memiliki pengaruh signifikan (memiliki $p$ value $<0,05)$ terhadap variabel dependen yaitu, konservatisme akuntansi (KA) sebesar 0,0000; sedangkan variabel pengungkapan corporate social responsibility (CSR) tidak memiliki pengaruh signifikan (memiliki $p$ value > 0,05) terhadap variabel dependen yaitu sebesar 0,5078. Nilai Adjusted $R$ Squared yaitu sebesar 0,956073 artinya secara variabel dependen dapat dijelaskan dalam model sebesar 96\% sedangkan 4\% lainnya dapat dijelaskan oleh faktor lain yang tidak termasuk dalam model.

Hasil uji Chow dengan program eviews 7 dapat dilihat pada tabel 4 berikut:

Tabel 4

Redundant Fixed Effects Tests

Hasil Uji Chow/Likelihood Ratio Test

Pool: Untitled

Test cross-section fixed effects

\begin{tabular}{lrrr}
\hline \hline Effects Test & Statistic & d.f. & Prob. \\
\hline \hline Cross-section F & 8.144720 & $(30,60)$ & 0.0000 \\
Cross-section Chi- & 151.013979 & 30 & 0.0000 \\
\hline \hline
\end{tabular}

Sumber : Hasil olah data dengan eviews 7

Hasil Uji Chow di atas menunjukkan bahwa nilai $\mathrm{F}$ hitung adalah sebesar 8,144720 sedangkan $\mathrm{F}$ tabel dari degree of freedom $(30,60)$ 1,64. Sementara pada taraf signifikansi $\alpha=5 \%$, dan dengan numerator 30 dan denumerator $60, \mathrm{~F}$ tabel adalah sebesar 1,64. Dengan demikian $\mathrm{F}$ hitung $>\mathrm{F}$ tabel $(8,144720>1,64)$. Uji Chow diatas juga menunjukkan bahwa nilai $\mathrm{F}$ test signifikan (pvalue $0.0000<0,05$ ), sehingga $\mathrm{H}_{0}$ ditolak yang berarti penelitian ini menggunakan Fixed Effect Model lebih baik dibandingkan dengan Common Effect Model.

Hasil uji Hausman dengan program eviews 7 dapat dilihat pada tabel 5 berikut: 


\section{Tabel 5}

\section{Hasil Uji Hausman}

Correlated Random Effects - Hausman Test

Pool: Untitled

Test cross-section random effects

\begin{tabular}{lrrr}
\hline \hline Test Summary & Chi-Sq. Statistic & Chi-Sq. d.f. & Prob. \\
\hline \hline Cross-section random & 0.289021 & 2 & 0.8654 \\
\hline \hline
\end{tabular}

Sumber : Hasil olah data dengan eviews 7

Hasil Uji Hausman di atas terlihat Model. bahwa nilai chi hitung 0,289021 lebih kecil dari chi tabel 5,99 dan p-value 0,289021 > 0,05 ( $\alpha$ ) maka Ho diterima dan Ha ditolak. Dengan demikian dapat disimpulkan bahwa baik dibandingkan dengan Fixed Effect penelitian ini hasil Random Effect Model lebih

$$
\begin{gathered}
\boldsymbol{Y}_{i t}=\propto+\boldsymbol{\beta}_{1} \boldsymbol{X}_{1 i t}+\boldsymbol{\beta}_{2} \boldsymbol{X}_{2 i t}+\boldsymbol{\varepsilon}_{i t} \\
\text { DA }=-0.029004-0.951527 \mathbf{K A}-0.023245 \text { CSRDI }
\end{gathered}
$$

Hasil pengujian membentuk model regresi data panel yang dapat menjelaskan pengaruh variabel independen terhadap variabel dependen secara terperinci dan penjelasannya dapat dilihat sebagai berikut:

1. Variabel Konstanta $(\propto)$

Konstanta sebesar $\quad-0,029004$ menyatakan bahwa tanpa ada pengaruh dari dua variabel independen dan faktor lain, maka variabel manajemen laba (DA) pada perusahaan pertambangan yaitu sebesar -0,029004 satuan.

2. Variabel Konservatisme Akuntansi (KA)
Koefisien regresi variabel konservatisme akuntansi bernilai 0,951527 (negatif). Hal ini berarti bahwa setiap terjadi peningkatan konservatisme akuntansi sebesar satu satuan, maka akan menurunkan manajemen laba perusahaan pertambangan yaitu sebesar -0.951527 satuan tanpa dipengaruhi faktor lainnya.

3. Variabel Pengungkapan Corporate Social Responsibility (CSR)

Koefisien regresi variabel pengungkapan corporate social responsibility (CSR) bernilai - 
0,023245 (negatif). Hal ini berarti bahwa setiap terjadi peningkatan pengungkapan corporate social responsibility (CSR) sebesar satu satuan, maka akan menurunkan manajemen laba perusahaan pertambangan yaitu sebesar $-0,023245$ satuan tanpa dipengaruhi faktor lainnya.

Hasil uji $\mathrm{F}$ menunjukkan bahwa $\mathrm{F}$ hitung adalah sebesar 1002,198 lebih besar dari $\mathrm{F}$ tabel dengan degree of freedom, $\alpha$ $(0,05)$ yaitu 3,30 . Nilai $p$-value 0,000000 lebih kecil dari 0,05 maka $\mathrm{H}_{1}$ diterima, ini berarti bahwa konservatisme akuntansi dan pengungkapan corporate social responsibility (CSR) secara simultan berpengaruh signifikan terhadap manajemen laba (H1 diterima).

Berdasarkan pada uji t, pengujian variabel konservatisme akuntansi terhadap variabel manajemen laba menunjukkan nilai t hitung senilai -44,19563 lebih kecil dari t tabel senilai -1,98580 dan $p$-value $0,000<0,05$ ( $\alpha$ $=5 \%$ ) sehingga $\mathrm{H}_{1}$ diterima. Artinya bahwa konservatisme akuntansi berpengaruh signifikan terhadap manajemen laba $\mathbf{( H}_{2}$ diterima). Pengujian variabel pengungkapan corporate social responsibility (CSR) terhadap variabel manajemen laba menunjukkan nilai t hitung senilai $-0,664892$ lebih besar dari t tabel senilai -1,98580 dan $p$ value $0,5078>0,05(\alpha=5 \%)$ sehingga $\mathrm{H}_{0}$ ditolak. Artinya bahwa pengungkapan corporate social responsibility (CSR) tidak berpengaruh signifikan terhadap manajemen laba (H3 ditolak).

Dari hasil pengujian hipotesis yang telah dijelaskan diatas, maka secara sederhana dapat dilihat pada tabel 6 dibawah ini :

Tabel 6

Pengujian Hipotesis

\begin{tabular}{|c|c|c|c|c|c|c|}
\hline No & Hipotesis & $F_{\text {hitung }}$ & $\mathrm{F}_{\text {tabel }}$ & thitung & $\mathrm{t}_{\text {tabel }}$ & Kesimpulan \\
\hline 1. & $\begin{array}{l}\mathrm{H} 1=\mathrm{X} 1, \mathrm{X} 2, \text { secara } \\
\text { simultan berpengaruh } \\
\text { terhadap Y }\end{array}$ & 1002,19 & 3,30 & - & - & $\begin{array}{c}\mathrm{F}_{\text {hitung }}>\mathrm{F}_{\text {tabel }}, \\
\text { sehingga } \mathrm{H}_{1} \\
\text { diterima }\end{array}$ \\
\hline 2. & $\begin{array}{l}\mathrm{H} 2=\mathrm{X} 1 \text { berpengaruh } \\
\text { signifikan terhadap } \mathrm{Y}\end{array}$ & - & - & $-44,13$ & $-1,98$ & $\begin{array}{c}\mathrm{t}_{\text {hitung }}<-\mathrm{t}_{\text {tabel }}, \\
\text { sehingga } \mathrm{H}_{2} \\
\text { diterima }\end{array}$ \\
\hline 3. & $\begin{array}{l}\mathrm{H} 3=\mathrm{X} 2 \text { tidak } \\
\text { berpengaruh signifikan } \\
\text { terhadap Y }\end{array}$ & - & - & $-0,66$ & $-1,98$ & $\begin{array}{c}\mathrm{t}_{\text {hitung }}>-\mathrm{t}_{\text {tabel }}, \\
\text { sehingga } \mathrm{H}_{3} \\
\text { ditolak } \\
\end{array}$ \\
\hline
\end{tabular}

Sumber: Hasil olah data dengan eviews 7 
Hasil penelitian ini menunjukkan bahwa nilai Adjusted $R$-squared sebesar 0,956073. Hal ini menunjukkan bahwa mekanisme konservatisme akuntansi dan pengungkapan corporate social responsibility (CSR) memberikan pengaruh sebesar 95,6\% terhadap manajemen laba serta mempunyai korelasi keeratan yang sangat kuat sekali antara variabel independen dengan variabel dependen dan sisanya yaitu sebesar $4,4 \%$.

\section{Pembahasan}

\section{Pengaruh Konservatisme Akuntansi Terhadap Manajemen Laba}

Penelitian ini membuktikan secara empiris bahwa konservatisme akuntansi berpengaruh signifikan terhadap manajemen laba. Variabel konservatisme akuntansi menunjukkan nilai t hitung senilai -44,19563 lebih kecil dari t tabel senilai -1,98580 dan $p$ value $0,000<0,05(\alpha=5 \%)$ sehingga $\mathbf{H}_{2}$ diterima. Artinya bahwa konservatisme akuntansi berpengaruh signifikan terhadap manajemen laba. Semakin konservatif laporan keuangan tersebut maka semakin kecil tindakan manajer untuk memanipulasi informasi-informasi dilaporan keuangan sehingga kecil kemungkinan manajer melakukan tindakan manajemen laba.

Menurut (Prabaningrat, 2015) konservatisme akuntansi dapat dijelaskan dari perspektif teori keagenan, manajer memiliki kesempatan untuk memaksimalkan kesejahteraannya sendiri dengan mengorbanankan kepentingan pemegang saham. Potensi konflik sebagai akibat adanya pemisahan antara pihak agen dan prinsipal dapat berpengaruh terhadap kualitas laba perusahaan. Pihak agen (manajemen) cenderung akan melakukan pelaporan keuangan sesuai dengan tujuannya dengan tidak memperhatikan kepentingan prinsipal.

Manajemen akan menggunakan sifat kehati-hatian agar laba yang dilaporkan tidak overstate. Sifat kehati-hatian digunakan semakin tinggi ketika manajemen melaporkan laba yang rendah (income decreasing), karena manajemen cenderung kurang agresive dalam melaporkan laba agar tidak terjadi overstate. Semakin tinggi penggunaan praktik konservatisma akuntansi maka semakin tinggi penggunaan praktik manajemen laba (Soraya \& Harto, 2014).

Hasil penelitian ini menunjukkan hasil yang sama dari penelitian yang sebelumnya dilakukan oleh (Prabaningrat, 2015) dan (Ruwanti, 2016) yang menunjukkan bahwa variabel konservatisme akuntansi berpengaruh terhadap manajemen laba, namun penelitian ini menunjukkan hasil yang berbeda dengan penelitian (Soraya \& Harto, 2014) dan (Ongki \& Pangestu, 2017) yang 
menyatakan bahwa konservatisme akuntansi tidak berpengaruh terhadap manajemen laba.

\section{Pengaruh Pengungkapan Corporate Social}

Responsibility

(CSR)

Terhadap

\section{Manajemen Laba}

Penelitian ini membuktikan secara empiris bahwa pengungkapan corporate social responsibility (CSR) tidak berpengaruh terhadap manajemen laba. Variabel pengungkapan corporate social responsibility (CSR) menunjukkan nilai t hitung senilai 0,664892 lebih besar dari t tabel senilai 1,98580 dan $p$-value $0,5078>0,05(\alpha=5 \%)$ sehingga $\mathbf{H}_{3}$ ditolak. Artinya bahwa pengungkapan corporate social responsibility (CSR) tidak berpengaruh signifikan terhadap manajemen laba. Semakin sering suatu perusahaan mengungkapkan corporate social responsibility (CSR) tiap tahunnya, maka dapat meminimalisir tindakan manajemen laba pada perusahaan tersebut.

Pelaksanaan CSR perusahaan erat kaitannya dengan teori legitimasi. Perusahaan berharap dapat beroperasi dengan tenang, sehingga membutuhkan dukungan (legitimasi) dari lingkungan masyarakat. Suatu perusahaan yang memiliki kontrak dengan masyarakat untuk melakukan kegiatannya berdasarkan nilai-nilai justice, dan bagaimana perusahaan menanggapi berbagai kelompok kepentingan untuk melegitimasi tindakan perusahaan, pernyataan ini sesuai dengan teori legitimasi. (Ricardo \& Faisal, 2015) menyatakan bahwa bahwa CSR merupakan tanggung jawab perusahaan terhadap masyarakat. Perusahaan yang berkontribusi terhadap CSR tidak hanya berfokus pada profit, namun juga ikut andil dalam pengembangang kesejahteraan masyarakat. Perusahaan yang secara sosial bertanggungjawab tidak akan menyembunyikan realisasi pendapatan yang tidak diinginkan, dan karenanya tidak akan melakukan manajemen laba.

Hasil penelitian ini menunjukkan hasil yang sama dengan yang sebelumnya dilakukan oleh (Putriana et al., 2018) dan (Almahrog et al., 2018) yang menyatakan bahwa corporate social responsibility tidak berpengaruh terhadap manajemen laba. Perusahaan dengan pengungkapan CSR yang lebih tinggi akan cenderung terikat dengan manajemen laba yang rendah. Meningkatkan relasi dengan para pemegang saham dan memberikan informasi - informasi keuangan secara keseluruhan lebih baik daripada hanya berfokus pada memanipulasi keuntungan perusahaan. Oleh karena itu, kegiatan corporate social responsibility (CSR) ini dapat memotivasi manajer untuk memiliki sikap yang jujur dan dapat dipercaya. 


\section{KESIMPULAN DAN SARAN}

\section{Kesimpulan}

Kesimpulan yang dapat diambil adalah konservatisme akuntansi dan pengungkapan corporate social responsibility (CSR) secara simultan berpengaruh terhadap manajemen laba. konservatisme akuntansi secara parsial berpengaruh terhadap manajemen laba. Pengungkapan corporate social responsibility (CSR) secara parsial tidak berpengaruh terhadap manajemen laba.

\section{Keterbatasan dan Saran}

Beberapa saran yang diharapkan dapat digunakan dalam penelitian selanjutnya sebaiknya menambahkan periode pengamatan, sebab semakin lama interval waktu pengamatan maka semakin besar pula kesempatan untuk memperoleh informasi yang akurat dan handal. Peneliti selanjutnya sebaiknya memperluas sampel penelitian di sektor-sektor perusahaan lainnya karena

\section{DAFTAR PUSTAKA}

Almahrog, Y., Ali Aribi, Z., \& Arun, T. (2018). Earnings management and corporate social responsibility: UK evidence. Journal of Financial Reporting and Accounting. https://doi.org/10.1108/JFRA-11-20160092

Arief, A., \& Ardiyanto, M. D. (2014). Pengaruh Pengungkapan Corporate Social Responsibility Terhadap sampel penelitian ini hanya sebatas pada perusahaan pertambangan. Peneliti selanjutnya sebaiknya menambahkan beberapa variabel independen yang lain yang memungkinkan dapat berpengaruh terhadap manajemen laba seperti kompensasi bonus dan komisaris independen.

Dalam penelitian ini pula terdapat keterbatasan-keterbatasan yang dapat menjadi bahan pertimbangan bagi peneliti selanjutnya. Peneliti terkendala dengan adanya perusahaan yang memliki data yang kurang lengkap sehingga sampel penelitian tereliminasi. Dalam mendeteksi manajemen laba, peneliti hanya menggunakan 2 variabel independen yang memiliki pengaruh sebesar $95,6 \%$ terhadap manajemen laba. artinya, masih terdapat slot sebesar $4,4 \%$ bagi variabelvariabel lain yang dapat digunakan untuk mendeteksi manajemen laba.

Manajemen Laba (Studi Kasus Pada Non Keuangan Dan Jasa Yang Terdaftar di Bei Tahun 2010-2012). Diponegoro Journal of accounting, 3(2003), 1-9.

Ferdiansyah, V. (2014). Pengaruh Kualitas Audit, Kompensasi Bonus, Struktur Kepemilikan, Dan Ukuran Perusahaan Terhadap Manajemen Laba. Jurnal TEKUN, 2, 20.

Ghozali, I., \& Chairiri, A. (2007). Teori Akuntansi. Universitas Diponegoro (Edisi 3). Badan Penerbit Universitas Diponegoro. 
Hans, K., Sinaga, R. U., \& Syamsul, M. (2012). Akuntansi Keuangan berdasarkan SAK berbasis IFRS. In Akuntansi Keuangan berdasarkan SAK berbasis IFRS. Jakarta: Salemba.

Haque, A., Mughal, A., \& Zahid, Z. (2016). Earning Management and the Role of Accounting Conservatism at Firm Level. International Journal of Economics and Finance, $8, \quad 1-10$. https://doi.org/10.5539/ijef.v8n2p197

Indrianto, \& Supomo. (2016). Metodologi Penelitian Bisnis untuk Akuntansi dan Manajemen. Yogyakarta: Penerbit BPFE. $\quad$ https://doi.org/10.1016/S15710866(07)80050-9

Mardikanto, T. (2014). CSR (Corporate Social Responsibility) (Tanggung jawab Sosial Korporasi). In CSR (Corporate Social Responsibility) (Tanggung jawab Sosial Korporasi) (Cetakan Ke, hal. 232). Bandung: Alfabeta.

Ongki, S., \& Pangestu, S. (2017). Determinan Dan Konsekuensi Konservatisme Akuntansi: Mekanisme Corporate Governance Dan Manajemen Laba. BALANCE, 15(1), 90-112.

Prabaningrat, I. G. A. A. (2015). Pengaruh Good Corporate Governance Dan Konservatisme Akuntansi Pada Manajemen Laba. E-Jurnal Akuntansi Universitas Udayana, 3(8), 663-676.

Prasetya, P. J., \& Gayatri. (2016). Pengaruh Ukuran Perusahaan terhadap Manajemen Laba dengan Pengungkapan Corporate Social Responsibility sebagai Variabel Intervening. e-Jurnal Akuntansi Universitas Udayana, 14, 511-538. https://doi.org/10.1016/j.biomaterials.20 13.11.006

Putriana, M., Artati, S., \& Junica, U. V. (2018). Pengaruh Corporate Social Responsibility Terhadap Manajemen Laba Dengan Leverage Dan Growth Sebagai Variabel Control Pada Industri Farmasi Yang Terdaftar Di Bursa Efek
Indonesia. J-MAS (Jurnal Manajemen dan Sains), 3(2), 137-145.

Ricardo, D. M., \& Faisal. (2015). Pengaruh Pengungkapan Corporate Social Responsibility Terhadap Manajemen Laba Dengan Industri. Diponegoro Journal of Accounting, 4(2337-3806), $1-9$.

Ruwanti, S. (2016). Pengaruh Konservatisme Akuntansi pada Manajemen Laba. Journal of Accounting and Economics. https://doi.org/http://dx.doi.org/10.1080/ 10106049.2015.1047470

Salno, H. M., dan Z. B. (2000). Analisis Perataan Penghasilan ( Income Smoothing): Faktor-faktor yang mempengaruhi dan Kaitannya dengan Kinerja Saham Perusahaan di Indonesia. Jurnal Riset Akuntansi Indonesia, 3, 1734.

Savitri, E. (2016). Konservatisme Akuntansi: Cara Pengukuran, Tinjauan Empiris dan Faktor-Faktor yang Mempengaruhinya. In M. S. Musfialdi (Ed.), Konservatisme Akuntansi: Cara Pengukuran, Tinjauan Empiris dan Faktor-Faktor yang Mempengaruhinya (1 ed., hal. 103). Yogyakarta: Pustaka Sahila Yogyakarta.

Septian, A., \& Anna, Y. D. (2014). Pengaruh Kepemilikan Manajerial, Ukuran Perusahaan, Debt Covenant dan Growth Opportunities Terhadap Konservatisme Akuntansi. e-Proceeding of Management.

Siregar, N. Y. \& Y. V. (2017). Pengaruh Corporate Social Responsibility Disclosure, Diversifikasi Perusahaan, Kompensasi Bonus, Dan Kualitas Audit Terhadap Earnings Management. Jurnal Akuntansi \& Keuangan, 8(1), 38-35. https://doi.org/10.1111/j.14697610.2010.02280.x

Soraya, I., \& Harto, P. (2014). Pengaruh Konservatisma Akuntansi terhadap Manajemen Laba dengan Kepemilikan Manajerial sebagai Variabel Pemoderasi. 
Diponegoro Journal of Accounting, 3, 111.

Sulistyanto, S. (2014). Manajemen Laba: Teori dan Model Empiris. In M. A. Listyandari (Ed.), Manajemen Laba: Teori dan Model Empiris (2 ed., hal. 276). Jakarta: PT Grasindo. https://doi.org/10.1021/ol302668y

Susanto, B., \& Tiara, R. (2016). Faktor-Faktor yang Memengaruhi Konservatisme. Jurnal Bisnis dan Ekonomi, 23(2), 142 151.

Wardani, D. K., \& Santi, desifa santi. (2018). Pengaruh Tax Planning, Ukuran Perusahaan, Corporate Social Responsibility (CSR) Terhadap Manajemen Laba. Jurnal Akuntansi, 6(1), 11-24. 